\title{
Üniversite Öğrencilerinin Kurumsal Etkinliklere İlişkin Görüşlerinin Değerlendirmesi: Artvin Çoruh Üniversitesi Örneği
}

\author{
$* * *$

\section{Evaluation of University Students' Opinions on Institutional Activities: A Case of Artvin Coruh University}

\author{
Asiye Işık \\ Ardahan Üniversitesi, Lisansüstü Eğitim Enstitüsü, asiye_84@artvin.edu.tr \\ ORCID: 0000-002-6328-5344 \\ Dr. Öğr. Üyesi Onur Akçakaya \\ Ardahan Üniversitesi, İIBF, onurakcakaya@ardahan.edu.tr \\ ORCID: 0000-0002-7328-5380
}

\begin{abstract}
Özet
$\mathrm{Bu}$ çalışma, Artvin Çoruh Üniversitesi lisans öğrencilerinin üniversite tarafindan halkla ilişkiler kapsamında gerçekleştirilen etkinliklere yönelik görüşlerini değerlendirmeyi amaçlamaktadır. Çalışmada betimsel araştırma yöntemi ve yüz yüze görüşme tekniği kullanılmıştır. Araştırma evreni ve örneklemi göz önünde bulundurularak katılımcılara yönelik olarak toplam 400 anket uygulanmıştır. Anketlerden elde edilen veriler, SPSS 12,0 programı kullanılarak analiz edilmiş ve yorumlanmıştır. Verilerin analizinde yüzde/frekans dağılımı tabloları kullanılmıştır. Araştırmadan elde edilen bulguların bazılarına göre, üniversite tarafından düzenlenen etkinlikler öğrencilerin büyük bölümü tarafından ilgi çekici bulunmaktadır. Buna rağmen, etkinliklere katılım sıklıkları beklenen seviyenin altında gerçekleşmiştir. Öğrencilerin etkinlikleri haber almasında internet en etkili araç olarak tespit edilmiştir. İkinci sırada ise üniversite tarafından hazırlanan afiş ve broşür gibi yazılı ve görsel iletişim araçları gelmektedir. Araştırmanın bir başka sonucuna göre öğrenciler sosyal, kültürel ve sportif etkinlikleri bilimsel etkinliklere nazaran daha fazla tercih etmektedir.
\end{abstract}

Anahtar Kelimeler: Kamu yönetimi, yerinden yönetim, halkla ilişkiler, kurumsal etkinlikler.

JEL Sınıflandırması: Z0

\begin{abstract}
This study aims to evaluate the opinions of Artvin Coruh University undergraduate students towards the activities within the scope of public relations. In this study, descriptive research method and face to face interview technique are used in the study. Considering the research universe and sample, a total of 400 questionnaires are applied to the participants. The data obtained from the surveys are analysed and interpreted using the SPSS 12.0 program. Percentage / frequency distribution tables were used in the analysis of the data. According to some findings of the research, the activities organized by the university are interesting for the majority; however, the frequency of participation is below expected levels. The internet has been identified as the most effective tool for students to be informed about the activities. The second place is written and visual communication tools such as posters and brochures prepared by the university. According to another result of the research, students prefer social, cultural and sports activities rather than scientific ones.
\end{abstract}

Keywords: Public Management, decentralization, public relations, corporate events.

JEL Classification: Z0 


\section{GİRIŞ}

Dinamik bir özelliğe sahip olan kamu yönetimi disiplini, zamanın ve mekânın şartlarına göre kendisini güncellemektedir. Zira, sanayi devrimi, ekonomik buhranlar, dünya savaşları, bilgi ve iletişim teknolojilerindeki gelişmeler ve küreselleşme kamu yönetimine önemli derecede etki etmiştir (Altan, 2016: 382). Özellikle de küreselleşmenin yadsınamaz düzeydeki etkileri neredeyse bütün ülkelerin kamu yönetimi yapılarında benzer düzlemlerde gerçekleşmiştir (Demirkaya, 2006: 133). Kamu yönetimini değişime zorlayan dinamikleri sadece iç ve diş dinamikler üzerinden değerlendirmek yetersizdir. Bu bağlamda, bir takım teorik yaklaşımların disiplin üzerindeki etkilerinden söz etmek gerekmektedir. Sırasıyla liberalizm, Keynesyen iktisat modeli-refah devleti ve neo-liberalizm gibi yaklaşımlar kamu yönetimini etki altına almıştır. Bununla birlikte işletme yönetimi ve yönetim biliminde geliştirilen yenilikçi araç ve süreçler de kamu yönetimini değiştirip dönüştürmüştür (Bozlağan, 2008a: 1). Bu çerçevede, günümüzde kamu yönetimi anlayışı modern dünyanın yeni değerlerini bünyesinde barındıran bir disipline dönüşmüştür. Etkinlik, verimlilik, hesap verebilirlik, açıklık, şeffaflık, yönetişim, esneklik, performans odaklılık, rekabetçilik ve çıtı odaklılık olarak sıralayabileceğimiz bu değerler dizisi, kamu yönetimine iyi işleyen bir örgüt yapısı kazandırmanın yanı sıra vatandaşların memnuniyetini sağlamada da önem arz etmektedir (Altan, 2016: 382).

Kamu yönetiminin görece yeni değerleri içerisinde şeffaflık ve açıklı örgütler için ayrı bir öneme sahiptir. Şeffaf ve açık bir örgüt yapısına sahip olmak vatandaşların beklentilerinin karşılanmasının yanı sıra yöneticilerle yönetilenler arasındaki iletişımin sağlanması; hedef kitlenin desteğinin alınması ve hedef kitlenin talep ve beklentilerine uygun kurumsal çıtıllar üretilmesi gibi avantajları da beraberinde getirir. Ancak bu avantaj üstünlügünü elde etmek; yönetim ile halk arasında dinamik ve aktif iletişim döngüsünü sağlamak için halkla ilişkiler gibi bir takım yönetim araçları zorunlu hale gelmektedir (Metin ve Altunok, 2002: 79-80). Bu bağlamda, halkla ilişkiler faaliyetlerinin kamu örgütleri için büyük önem taşıdığını söyleyebiliriz. Ancak halkla ilişkiler etkinlikleri kadar bu etkinliklerin performansının ölçülmesi de önemlidir. Performans değerlendirmesi örgüte birtakım faydalar sağlar. Etkinlik performansının değerlendirilmesi öncelikle hedef kitlenin kurumsal etkinliklerden duyduğu memnuniyet düzeyinin belirlenmesine hizmet eder. Halkla ilişkiler etkinlikleri vatandaşlara yönelik olduğundan onların görüşlerinin değerlendirilmesi son derece önemlidir. Zira, kurum yöneticileri tarafindan etkinliklerin yeterli olup olmadığı hakkında somut bilgiler edinebilmesi buna bağlıdır. Bu sayede kurumsal etkinliklere yönelik etkin olmayan stratejiler tespit edilebilir ve bunlar üzerinde revizyon yapılabilir.

$\mathrm{Bu}$ araştırmanın amac1, Artvin Çoruh Üniversitesi'nce düzenlenen bilimsel, sosyal, kültürel ve sportif etkinliklere yönelik lisans öğrencilerinin görüşlerini değerlendirmektir. Araştırma sonuçlarının üniversitenin kurumsal etkinlik performansının belirlenmesine dolayısıyla kurumsal kapasitenin artırılmasına yardımcı olacağı düşünülmektedir. Çalışma dört kısımdan oluşmaktadır. Birinci kısımda halkla ilişkiler kavramının ortaya çıkışı, gelişimi ve kamu örgütlerinde halkla ilişkiler faaliyetlerine yönelik teorik bir çerçeve çizilmektedir. İkinci kısımda halkla ilişkiler etkinliklerine yönelik geniş bir literatür taraması yapılmaktadır. Üçüncü kısımda çalışmanın yöntemi hakkında açıklayıcı bilgiler verilmektedir. Dördüncü kısımda ise araştırma bulguları ortaya konmakta ve tartışılmaktadır.

\section{KAVRAMSAL ÇERÇEVE}

\subsection{Halkla İlişkiler Kavramının Ortaya Çıkışı ve Gelişimi}

Modern anlamda ortaya çıkışı 19. yüzyıl sonlarına rastlayan halkla ilişkiler disiplini (Byerly, 1993; RobertsBowman, 2016), o tarihlerden günümüze sosyal bilimciler ve uygulayıcıların ilgisini çekmektedir (RobertsBowman, 2016: 5). Halkla ilişkiler uygulamaları, son yıllardaki gelişmelerle birlikte rutin ve profesyonel etkinliklere dönüşmüştür. Bunun yanı sıra etik yaklaşımlar ve eğitim faaliyetleri gibi alanlarda da yeniden ele alınmıştır. Ancak halkla ilişkilerin ortaya çıkışını ve gelişimini 19. yüzyıl sonrasıyla sınırlandırmak 
doğru değildir. Çoğu araştırmacı, halkla ilişkilerin köklerini yüzyıllar öncesine dayandırmaktadır. Zira halkla ilişkiler eski çağlarda propaganda yapmak ve kamuoyunu yönlendirmek amaçlarıyla birçok kişi ya da kişilerce kullanılmıştır. Propaganda faaliyetleri duruma göre, siyasi ve dini amaçlarla gerçekleştirilmiştir. Örneğin, 11. ve 13. yüzyıllar arasında Katolik Kilisesi’nin haçlı seferlerini teşvik etme propagandaları tarihteki erken halkla ilişkiler faaliyetleri olarak değerlendirilmektedir (Byerly, 1993: 2). Bu konuda İnalcık (2019: 17), Papalı̆̆ın propagandalarının Osmanlı’nın Bizans üzerinde tehlike arz etmeye başlaması ile birlikte 14. ve 15. yüzyıllarda da sürdügünü belirtmektedir. Katolik Kilisesi'nin ruhani lideri olan Papalar propaganda faaliyetlerini, Avrupa'daki krallara baskı yapmak ve Türklere karşı savaşmanın kutsal olduğuna halkı inandırmak suretiyle yürütmüşlerdir (İnalcık, 2019: 17). Buradan bir çıkarımla Katolik Kilisesi'nin haçlı bilincini uyandırmaya yönelik propaganda faaliyetlerinin 11. yüzyıldan 16. yüzyıla değin sürdüğünü ve bu faaliyetlerin halkla ilişkilerin tarihsel gelişiminde göz ardı edilmemesi gerektiğini söyleyebiliriz.

Literatürde kredi hacmi ile ekonomik büyüme arasındaki ilişkiye yönelik çalışmalar daha çok finansal gelişme ve ekonomik büyüme kapsamında ele alınmaktadır. Finansal gelişmenin ekonomik büyümeyi mi yoksa ekonomik büyümenin finansal gelişmeyi mi sağladığı sorusunun cevabının tespiti için yapılan çalışmalarda farklı sonuçlara ulaşılmıştır. Roberts-Bowman gibi bazı araştırmacılar ise halkla ilişkilerin tarihçesini çok daha gerilere götürmektedir. Halkla ilişkilerin iletişime dayanan yapısı onu tarihin her döneminde karşılaşılması muhtemel bir olgu haline getirmektedir. Halkla ilişkilere yönelik erken tecrübe örneklerinden birisi Roma döneminde görülmüştür. Şöyle ki, Julius Caesar döneminde, imparatorun başarılarını halka aktarmak ve onların desteğini almak amacıyla "Acta Diurna" isimli günlük gazete yayınlanmıştır. Öte yandan, Mısır'da sanat ve mimarinin firavun ve rahiplerinin kutsallığına halkı inandırmak amacıyla kullanılması gibi benzer örnekleri artırmak mümkündür (2016: 9).

Kısacası halkla ilişkilere yönelik faaliyetler tarih öncesi dönemlerden günümüze var ola gelmiştir. Bu uzun süreç içerisinde gerek kullanılan araçlar gerekse de perspektif bakımından halkla ilişkilerin köklü değişim ve dönüşüler geçirdiğini söyleyebiliriz (Roberts-Bowman, 2016: 10). Tablo 1 bu dönüşüm sürecini dönemler halinde göstermektedir.

Tablo 1. Halkla İlişkiler Perspektiflerine İlişkin Tarihsel Süreçler

\begin{tabular}{lcc}
\hline Açıklama & Anahtar Kelime & Dönem \\
\hline Halkla ilişkiler gelişen bir sosyal disipline dönüşmüştür. & $\begin{array}{c}\text { Gelişme, Küreselleşme, } \\
\text { Profesyonelleşme }\end{array}$ & 20. yüzyıll \\
\hline Halkla ilişkiler bir meslek alanı olarak ortaya çıkmıştır. & Modern anlamda ortaya çıkış & 19. yüzyıl \\
\hline Halkla ilişkiler örgütler düzeyinde ortaya çıkmıştır. & Örgütler arası iletişim & Ortaçağ sonu \\
\hline Halka açık iletişim görülmektedir. & Halkla iletişim & Antikçağ/ortaçağ \\
\hline Kişiler arası iletişim gözlenmiştir. & Kişiler arası iletişim & Antikçağ öncesi \\
\hline
\end{tabular}

Kaynak: Bentele, (2010)'dan aktaran: Roberts-Bowman, (2016:10).

Halkla ilişkiler kavramı üzerine birçok tanım yapılmasına rağmen genel geçer bir tanımdan söz etmek mümkün değildir. Bu durum, halkla ilişkilerin karmaşık yapısından kaynaklanmaktadır. Zira, halkla ilişkiler toplumun her kesimi ve hayatın her alanı ile yakın temas içerisindedir (Roberts-Bowman, 2016: 3). Bu çalışmada tanım sorununa odaklanmak gibi bir amacımız bulunmamakta; ancak çalışmaya katkı yapacağı düşüncesiyle bazı tanımlara değinilmektedir.

Daha öncede belirttiğimiz gibi literatürde halkla ilişkilerin tanımına yönelik bir uzlaşı bulunmamaktadır. Ancak yine de akademik çevrelerce kabul görmüş tanımlardan söz edebiliriz. Bunların en çok 
bilinenlerinden birisi Rex F. Harlow'a aittir. Halkla ilişkileri kurumlarla halk arasındaki bir ilişki düzleminde gören Harlow, şu şekilde bir tanım yapmaktadır (Harlow, 1976: 36):

"Halkla ilişkiler bir kuruluş ile vatandaşlar arasında karşılıklı iletişsim, anlayış, kabul ve iş birliği kurulmasına ve sürdürülmesine yardımcı olan kendine özgü bir yönetim işlevidir."

Harlow (1976: 36), halkla ilişkileri sorunların yönetimine yardımcı olan bir disiplin olarak kabul etmektedir. Bu faaliyetleri etkin bir şekilde uygulayan kurumlar, kamuoyunun talep ve beklentilerine uygun işlevler yürütebilir. Bunun aksi de geçerlidir. Halkla ilişkileri örgüt ile hedef kitle arasında gerçekleşen bir iletişim süreci olarak değerlendiren Grunig ve Hunt (1984:6) ise görece daha kısa bir tanım yapmışlardır. "Kurumlar ve halk arasindaki iletişimin yönetimi".

Kavrama ilişkin önemli bir tanım da 1978 tarihli Meksika Bildirisi'nde yapılmıştır. Bildiri halkla ilişkileri, "eğilimleri analiz etme, sonuçları tahmin etme, organizasyon liderlerine danışmanlı yapma ve hem kuruluş hem de kamu yararına hizmet edecek planlı eylem programlarinin uygulanması sanatı ve sosyal bilimi” olarak tanılamıştır (Roberts-Bowman, 2016: 5). Görüldüğü üzere, bu tanım stratejik düşünce temelinde yapılan ve halkla ilişkileri tüm kurumsal süreçlere yerleştiren bir tanımdır.

Buraya kadar yapılan tanımlardan anlaşılacağı üzere halkla ilişkiler disiplini genellikle "iletişim", "kurumsal süreçler" ve "strateji" gibi temalarla ilişkilendirilmiştir. Yazından hareketle, halkla ilişkileri örgütün ve hedef kitlenin faydasını gerçekleştirmeye yönelik, iletişime dayalı, tüm yönetim süreçlerinde geçerli bir yönetim fonksiyonu olarak tanımlayabiliriz. Bu tanım üzerinden halkla ilişkiler faaliyetlerinin gerek kamu gerekse de özel sektör örgütleri için son derece önemli olduğunu söyleyebiliriz.

\subsection{Kamu Örgütleri ve Halka İlişkiler}

Halkla ilişkilerin hedef kitlesi irili ufaklı topluluklardır. Bunlar bazen minimal gruplar bazen toplumun tümü olabilir. Hangi büyüklükte olursa olsun insan topluluklarının kendilerine özgü özellikleri, talep ve beklentileri bulunmaktadır. Tanıtma, duyurma, ikna etme ve etkileme gibi halkla ilişkiler çıktılarının etkin olabilmesi için bunların vatandaşların talep ve beklentileri ile uyuşması gerekir. Özellikle piyasa şartlarında halkla ilişkilerin etkin uygulamaları kritik önem taşır. Zira işletmeler rekabet avantajlarını yitirmemek için müşterilerin geniş yelpazedeki talep ve beklentilerine cevap vermek zorundadır. Ayrıca etkin kurumsal etkinlikler firmanın marka değerini, imajını ve hizmet kalitesini yükseltmektedir (Öndoğan, 2010: 441). Ancak müşteri memnuniyetini sağlamak, hizmet kalitesini yükseltmek ve kurumsal itibarını artırmak sadece özel sektör kuruluşlarının hedefleri arasında yer almaz. Modern yaklaşımlar kamuda da hızlı, etkin ve verimli bir örgüt yapısını zorunlu kılmaktadır.

Yeni yaklaşımlar 1980'lerden bu yana kamu yönetiminde etkili olmaktadır. Geleneksel teoriye ve Weberyan bürokrasiye bağl1lık giderek azalırken yeni paradigmalara olan ilgi teori ve pratikte artmaktadır. "Yeni kamu yönetimi", "yeni kamu işletmeciliği" ve "yeni kamu hizmeti" isimleriyle adlandırılan yeni yaklaşımlar kamu yönetiminin yapısal ve işlevsel sorunlarını çözmeyi; bürokratik yapıyı ise hızlılık, etkinlik, verimlilik, hesap verebilirlik, şeffaflık ve açıklık gibi değerler çerçevesinde dönüştürmeye amaçlamaktadır. Yeni yaklaşımların kuramsal temellerini "neo-bürokrasi kuramı", "kurumsal model yaklaşımı", "kamusal tercih kuramı", "mülkiyet hakları yaklaşımı" ve "insan ilişkileri yaklaşımı" oluşturmaktadır (Bozlağan, 2008: 10). İnsan ilişkileri yaklaşımının özellikleri olan kişiler ve gruplar arası ilişkiler, iletişim, isteklendirme, değişim, eğitim, otoritenin paylaşılması ve uzlaşma (Bozlağan, 2008: 11) bir nevi halkla ilişkiler disiplinin de temel değerlerini oluşturmaktadır. Bu bağlamda, kamu yönetiminde modern yaklaşımlar için halkla ilişkilerin önem arz ettiğini söyleyebiliriz.

Halkla ilişkiler faaliyetleri sadece bireylerin sosyalleşmesine yönelik uygulamalar olmayıp aslında kamu yönetiminde stratejik hedeflerin tutturulması gibi çok daha önemli amaçlar doğrultusunda kullanılırlar. $\mathrm{Bu}$ faaliyetler kurumların misyon ve vizyonlarına uygun hareket etmelerinde de ayrıca öneme sahiptir 
(Özkanal, 2014: 13). Kurumsal faaliyetlerin bir diğer işlevi yönetenlerle yönetilenler arasında iletişimin sağlanmasında köprü rolü üstlenerek yöneticilerin vatandaşların istek ve beklentilerini anlamalarına yardımcı olmasıdır. Bununla birlikte vatandaşların kamu stratejileri ile ilgili bilgi sahibi olmalarına da katkı sağlamaktadır. Ayrıca halkla ilişkiler örgütsel mesajların kaynaklarına hızlı, doğru, tutarlı ve şeffaf bir biçimde iletilmesini de sağlamaktadır (Uygun, 2018: 20).

Hızla küreselleşen ve dijitalleşen dünya düzeni her kamu kuruluşuna olduğu gibi üniversitelere de birtakım yükümlülükler yüklemektedir. Bunlardan bazıları müşteri memnuniyetini, öğrenci sayısını ve çeşitliliğini artırmak; kurumsal imajı güçlendirmek; kurumun bilimsel, kültürel ve sosyal gelişimini sağlamaktır. Üniversiteler bu amaçları gerçekleştirebilmek ve rekabet gücünü artırabilmek için halka ilişkiler faaliyetlerine rağbet göstermektedir (Öndoğan, 2010: 439). Çünkü iletişim seviyesi yüksek, planlı ve eşgüdümlü bir şekilde yürütülen halkla ilişkiler faaliyetleri marka değerlerini ve saygınlıklarını önemli derecede artırmaktadır. Kurumsal etkinlikler öğrenciler üzerinde de etkili olmakta; onların aidiyet geliştirmelerine ve bilimsel, sosyal ve kültürel alanlarda gelişmelerine imkan tanımaktadır (Özkanal, 2014: $15)$.

Son yıllarda ülkemizde kurulan diğer üniversiteler gibi Artvin Çoruh Üniversitesi de 17 Mayıs 2007 tarihli ve 5662 sayılı kanunla kurulmuştur. İlgili kanun 29 Mayıs 2007 tarih ve 26736 sayılı Resmî Gazete 'de yayımlanarak yürürlüğe girmiştir. Üniversite il merkezindeki "Şehir Yerleşkesi" ve "Seyitler Yerleşkesi" ile Hopa ilçesinde bulunan "Hopa Yerleşkesinden” oluşmaktadır (Beşballı ve Öztürk, 2017: 140).

Artvin Çoruh Üniversitesi bünyesinde bulunan birimler aracıllğıyla bir takım halka ilişkiler etkinlikleri yürütmektedir. Örneğin, genel sekreterliğe bağlı Basın ve Halkla İlişkiler Ofisi tarafından üniversitenin misyon ve vizyonunun hedef kitleye aktarılmasına ve üniversite birimleri arasında iletişimin sağlanmasına yönelik faaliyetler yürütülmektedir. Bunun yanında yerel ve ulusal basınla ilişkilerin doğrudan ya da dolaylı olarak yürütülmesi amaciyla kurumsal dergi, fotoğraf, video-film, sunu, broşür gibi yazılı ve görsel ağırlıklı tanıtım materyallerinin hazırlanması ve dağıtımı gibi faaliyetler gerçekleştirilmektedir. Üniversitenin sosyal ve kültürel etkinliklerinin yürütülmesinden Sağl1k Kültür ve Spor Daire Başkanlığı sorumludur. Bu faaliyetler kapsamında öğrencilere yönelik tanışma geceleri, halk oyunları, tiyatro gösterileri, festivaller, şenlikler, gezi programları, gösteriler, kampanyalar ve konserler gibi etkinlikler düzenlenmektedir. Ayrıca üniversite bünyesinde çalıştay, eğitim, konferans, kongre, panel, seminer ve sempozyum gibi bilimsel etkinliklere de yer verilmektedir ${ }^{1}$. Tablo 2 Artvin Çoruh Üniversitesi'nde düzenlenen etkinliklerin y1llara göre dağılımını göstermektedir:

Tablo 2. Artvin Çoruh Üniversitesi’nde Düzenlenen Etkinliklerin Yıllara Göre Dağılımı

\begin{tabular}{ccccc}
\hline Yıl & Sos/Kül/ Bil. & Sportif & Diğer & Toplam \\
\hline 2015 & 39 & 8 & 10 & 57 \\
2016 & 57 & 8 & 21 & 86 \\
2017 & 47 & 9 & 49 & 105 \\
2018 & 44 & 31 & - & 75 \\
\hline
\end{tabular}

(Kaynak: www.artvin.edu.tr)

\section{LITERATÜR TARAMASI}

Halkla ilişkiler literatüründe kuramsal ve deneysel nitelikte çok sayıda çalışma yapıldığı görülmektedir. Alandaki teorik çalışmaların en önemlilerinden birisi Harlow (1976) tarafından yapılmıştır. Bu çalışma halkla ilişkilerin örgütler ve hedef kitleler arasındaki bir iletişim süreci olduğuna odaklanmakla birlikte disiplinin tanımlanmasına yönelik erken bir çalışma olarak dikkat çekmiştir (Harlow, 1976). Harlow gibi halkla ilişkilerin kavramsal boyutuyla ilgilenen Grunig ve Hunt (1984: 6) ise halkla ilişkileri kurumla hedef 
kitle arasındaki bir iletişim süreci olarak değerlendirmişlerdir. İletişim odaklı bir diğer teorik çalışma Kent ve Taylor'ın (2002) çalışmasıdır. Araştırmacılar halkla ilişkilerin bir aracı olan diyaloğun önemine odaklanmıştır. Kent ve Taylor daha çok örgütsel ve kamusal faydanın sağlanması için vatandaşlarla diyaloğun nasıl ve neden kurulması gerektiği üzerinde durmuşlardır. Teorik bir çalışma olan Theaker (2016)'ın çalışması ise halkla ilişkilerin tanımı; paydaşları; politika, medya, strateji, iletişim ve yönetimle ilişkisi gibi konular üzerinde durmuştur.

Alikılıç ve Onat (2007) çalışmalarında kurumsal bloglar gibi yeni kitle iletişim araçlarının halkla ilişkiler uygulamalarındaki yeri üzerinde durmuşlardır. Çalışmada etkin kurumsal bloglar oluşturma stratejileri ve bloglardan başarılı bir şekilde yararlanan şirketlerin faaliyetleri yer verilmiştir. Yazarlar blogların halkla ilişkilerin temel ilkeleri ile bağdaştığını belirtmektedir. Onat ve Aşman-Alikılıç (2008) bir başka çalışmalarında bu kez hızla değişen enformasyon teknolojilerinin halkla ilişkiler disiplinindeki yeri üzerinde durmuşlardır. Yazarlara göre enformasyon teknolojilerinin hızlı bir gelişme göstermesi mesaj alıcılar, göndericiler ve geleneksel iletişim araçları üzerinde etkili olmaktadır. Sosyal ağlar yeni bir halkla ilişkiler mecrası olarak pazarlama iletişiminde önem arz etmektedir. Sosyal ağlar halkla ilişkiler açısından da bir takım avantaj ve dezavantajlar oluşturmaktadır.

Öner (2001) ise çalışmasında halkla ilişkilerin yerel yönetimlerde katılıma etkisi üzerinde durmaktadır. Buna göre, yerel yönetimlere katılımın artması iletişim faktörü ile yakından ilgilidir. Halkla ilişkiler faaliyetleri ise yerel halkın talep ve beklentilerinin yerel yöneticiler tarafından anlaşılmasında etkin bir araçtır.

Uzunoğlu ve Öksüz, (2008) çalışmalarında kurumsal itibar risk yönetimi ile etkin halkla ilişkiler uygulamaları arasındaki ilişkiye odaklanmışlardır. Buna göre, etkili uygulanan halkla ilişkiler faaliyetleri kurumsal paydaşlar ile sürekli, tutarlı ve çift yönlü iletişim becerilerini geliştirmekte dolayısıyla itibar risk yönetiminin her aşamasında etkili olmaktadır.

Yağmurlu (2011) kamuda halkla ilişkiler ve sosyal medya konulu bir çalışma yapılmıştır. Bu çalışmaya göre kamu yönetiminde bir halkla ilişkiler aracı olarak ele alınan sosyal medya, diyaloğa ve iletişime dayalı yapısıyla halkla ilişkilerin iki yönlü simetrik modeli ile ilişki içerisindedir. Kurumsal itibar yönetimi ve halkla ilişkiler uygulamaları arasındaki ilişkiyi ortaya koymaya yönelik bir diğer çalışma ise Ural (2002) tarafından yapılmıştır. Bu çalışma kurumsal etkinliklerin hem kuruma hem de hedef kitlelere değer yaratacak etkiler yarattığı sonucuna varmaktadır.

Halkla ilişkilerin ekonomik değerinin belirlenmesi üzerine bir araştırma Kim (2001) tarafından yürütülmüştür. $\mathrm{Bu}$ çalışma performans değerlendirmesi yapmak amacıyla yeni bir model önermektedir. Önerilen model iki ilişki üzerinden işlemektedir. Birincisi, halkla ilişkiler uygulamalarının kurumsal itibar üzerine etkisi, ikincisi ise itibarın karlılık üzerine etkisidir. Çalışmanın sonuçlarına göre, her iki ilişkide anlamlı bir ilgileşim elde edilmiştir. Ortaya atılan model, kurumsal çıktıların değerlendirilmesi için yeni bir yöntem olması açısından önemlidir.

Kurumsal etkinlik performansının değerlendirilmesini amaçlayan bir araştırma Hon ve Grunig (1999) tarafından yürütülmüştür. Araştırmacılar kurumsal etkinliklere yönelik altı temel alanda hazırlanan bir anketi katılımcılara uygulamışlardır. Araştırma kurumsal etkinlik performansının değerlendirilmesi açısından önem arz etmektedir.

Lindenwann (1997) halkla ilişkiler uygulamalarının etkinliğinin ölçülmesinde minimal standartların geliştirilmesine yönelik bir çalışma yapmıştır. Froehlich ve Rüdiger, (2006) ise Almanya'da siyasal iletişim stratejilerinin başarısının ölçülmesine yönelik bir araştırma yürütmüşlerdir. Çalışma siyasal iletişim sürecinde politikacıların ve gazetecilerin rollerini tespit etmeyi amaçlamaktadır. Araştıranın sonuçları gazetecilerin genel siyasi tartışmalar dışındaki konularda politikacıların siyasal mesajlarını değiştirme eğiliminde olduklarını göstermiştir. 
Waters, (2009) bağış toplama faaliyetleri üzerinden halkla ilişkiler yönetiminin performansının ölçülmesine yönelik bir çalışma yapmıştır. Çalışma, bağış toplamada karşılıklılık, sorumluluk, raporlama ve ilişki beslemenin etkilerini ölçmek amacıyla yeni ölçekler oluşturmuştur. Araştırmanın sonuçlarına göre kâr amacı gütmeyen kuruluşlarla bağışçılar arasındaki ilişkinin olumlu olarak değerlendirilmesi bağış̧̧̧ların ve bağış miktarındaki artışı da beraberinde getirmektedir.

Öndoğan (2010) çalışmasında Selçuk Üniversitesi Merkez Kütüphanesi'nde yürütülen halkla ilişkiler çalışmalarının etkinliğini ölçmeyi amaçlamıştır. Anket tekniğinin kullanıldığı çalışmada yararlanıcıların kütüphanenin fiziksel durumu ve hizmet koşulları ile ilgili memnuniyeti değerlendirilmiştir. Çalışmanın sonuçları yararlanıcıların fiziksel ve işlevsel unsurlardan memnuniyet oranının yüksek olduğunu buna karşın kütüphane dışındaki faaliyetlerden memnuniyet oranının düşük olduğunu göstermiş̧tir.

Saran, Coşkun, İnal-Zorel ve Aksoy, (2011) üniversitelerde sosyal sorumluluk bilincinin geliştirilmesine yönelik olarak verilen "Topluma Hizmet Uygulamaları" dersinin koordinasyonu ve uygulamalarının etkinliğine yönelik bir araştırma gerçekleştirmiş̧tir. Araştırmada bulgulara ulaşmak için yarı yapılandırılmış görüşme formları kullanılmış ve yüz yüze görüşmeler gerçekleştirilmiştir. Araştırmanın evrenini Ege Üniversitesi bünyesinde bulunan fakülte ve yüksekokullar oluşturmaktadır. Araştırmanın sonuçları kapsamında topluma hizmet uygulamaları biriminin kurulması, bilgilendirici kitapçıkların hazırlanması, web sitelerinin güncellenmesi, öğrencilerin farkındalığının artırılması gibi öneriler getirilmiştir.

Sarı, (2012) tarafından yapılan bir araştırmada lise öğrencilerinin müfredat dışındaki etkinliklere katılma oranlarının tespit edilmesi amaçlanmıştır. Araştırmanın örneklemini Adana'daki üç lisede eğitim gören öğrenciler oluşturmaktadır. Öğrencilere müfredat dışındaki etkinliklere katılım anketi uygulanmıştır. Araştırma sonuçlarına göre, öğrenciler kurumsal etkinliklere nadiren katılmaktadır. Ayrıca söz konusu etkinliklere katılımla eğitim düzeyleri ve sınıf performansları arasında anlamlı bir farklılık tespit edilmiştir.

Özkanal, (2014) tarafından yapılan başka bir araştırma Anadolu Üniversitesi öğrencilerinin üniversite tarafından gerçekleştirilen kurumsal etkinliklere yönelik katılımlarını değerlendirmiştir. Anket tekniğinden yararlanılan çalışmada verilerin analizi yüzde, frekans tabloları ve çapraz tablolar yardımıyla yapılmıştır. Araştırmanın sonuçları öğrencilerin etkinlikleri faydalı bulduklarını göstermektedir. Sanatsal ve kültürel etkinliklere daha fazla katılan öğrenciler spor ve eğitim etkinliklerinin artırılmasını istemektedir. Etkinliklerden haberdar olmak için öğrenciler tarafından basılı ve internet araçları sıklıkla kullanılmaktadır.

Yukarıdaki açıklamalardan hareketle halkla ilişkiler literatüründe teorik çalışmaların sıklıkla halkla ilişkilerin tanımı, tarihçesi ve kapsamı; diğer disiplinlerle ilişkisi; kamu ve özel sektörde yönetim süreçlerine katkısı; kamu ve özel sektörde yönetimle ilişkisi; iletişim, diyalog, siyaset ve medya ile ilişkisi, strateji ile ilişkisi, yeni yaklaşımlarla ilişkisi, yeni halkla ilişkiler araçları, yeni enformasyon teknolojilerinin halkla ilişkilere etkisi, sosyal medyanın halkla ilişkiler üzerindeki etkisi gibi konulara odaklandığını söyleyebiliriz. Öte yandan ampirik araştırmalar ise kurumsal etkinlik performansının ölçülmesi, halkla ilişkilerin ekonomik hedefler üzerindeki etkisi, kurumsal etkinliklerin kurumsal çıktılara etkisi, kurumsal faaliyetlerinin etkinliğinin ölçülmesi, kurumsal etkinliklerin marka imajı ve itibarı üzerine etkisi, vatandaşların kurumsal etkinliklere yönelik algıları, örgüt paydaşlarının kurumsal etkinliklere yönelik algıları, halkla ilişkiler uygulamalarının marka değeri ve karlılığa etkisi gibi konular üzerinde yoğunlaşmaktadır.

Kurumsal halkla ilişkiler faaliyetlerinin hedef kitle üzerindeki memnuniyet seviyesinin ölçülmesine yönelik araştırmalar büyük önem arz etmektedir. Bu suretle etkinliklere yönelik hedef kitlenin memnuniyet duyduğu ya da duymadığı alanlar tespit edilebilmektedir. Sonuçlara göre etkinlik stratejilerinde revizyona gidilebilmekte; mevcut aksaklıklar düzeltilebilmektedir. Böylelikle halkla ilişkiler etkinliklerinin niceliği ve niteliği yükseltilebilmektedir. Bu çerçevede, Özkanal (2014) ve Sarı (2012) tarafından yapılan çalışmalar önem arz etmektedir. Bu tür çalışmalar etkinlik performanslarını tespit etmek isteyen kurumlara büyük 
faydalar sağlamaktadır. Bu düşünceden hareketle, halkla ilişkiler faaliyetlerinden memnuniyet düzeyinin ölçülmesine yönelik bu çalışma, literatürdeki bir boşluğun doldurulması amacını taşımaktadır. Yapılan literatür araştırmasında Artvin Çoruh Üniversitesi öğrencilerinin kurumsal etkinliklere yönelik memnuniyet düzeylerini belirlemeyi amaçlayan bir çalışmaya rastlanmamıştır.

\section{METODOLOJI}

\subsection{Araştırmanın Amacı ve Türü}

Bu çalışma, Artvin Çoruh Üniversitesi’nde öğrenim görmekte olan üniversite öğrencilerinin üniversitece düzenlenen kurumsal etkinliklere yönelik memnuniyet düzeylerini belirlemeyi amaçlamaktadır. Burada kurumsal etkinlik kavramı ile kastedilen üniversite tarafından yürütülen sosyal, kültürel, bilimsel ve sportif etkinliklerdir. Araştırmanın amacı çerçevesinde bazı araştırma soruları belirlenmiştir. Bunlar aşağıdaki gibidir:

- Artvin Çoruh Üniversitesi'nin iç paydaşları olan öğrenciler üniversitenin yürüttüğü sosyal, kültürel, bilimsel ve sportif faaliyetleri yararlı bulmakta mıdır?

- Bu faaliyet türleri arasında memnuniyet açısından anlamlı bir farklılık bulunmakta mıdır?

- Öğrenciler kurumsal etkinliklere katılmak konusunda istekli midir?

- Öğrenciler kurumsal etkinliklerden katılmaktan mutlu olmakta mıdır?

- Öğrenciler kurumsal etkinliklere ne sıklıkta katılmaktadır?

- Öğrenciler en çok hangi enformasyon araçları vasıtasıyla etkinliklerden haberdar olmaktadır?

- Öğrencilerin kurumsal etkinliklerin daha nitelikli olması için talep ve beklentileri nelerdir?

\subsection{Araştırmanın Evreni ve Örneklem}

Araştırmamızın evrenini Artvin Çoruh Üniversitesi Merkez Yerleşkesinde öğrenim gören lisans öğrencileri oluşturmaktadır. Araştırmanın evrenini tam olarak tespit edebilmek amacıyla öğrenci sayısının tespit edilmesi gerekmiş; bunun için üniversiteye bağlı Öğrenci İşler Daire Başkanlığına başvurulmuştur. İlgili birimden alınan verilere göre, 2020 güz yarıyılı itibariyle üniversiteye ait merkez yerleşkesinde öğrenim gören öğrenci sayıs1 '7.079' olarak tespit edilmiştir. Merkez yerleşkesinde öğrenim gören öğrenci sayıs1 '7.079' olarak tespit edilmiştir. Tespit edilen evren sayısının çokluğu ve araştırma süresinin kısıtlılı̆̆g gibi etkenler göz önüne alınarak örneklemin oluşturulabilmesi için "kolayda örneklem yöntemine" (convenience sampling) başvurulmuştur. Krejcie (1970:608)'nin verdiği evren ve örneklem sayıları tablosunda evreni 7000 olan bir çalışmanın '364' kişiye uygulanması ile araştırma evreninin temsil edildiği belirtilmiştir. Bu çalışmaya dayanarak, gerekli örneklem sayısına ulaşabilmek için toplam 400 öğrenciye anket uygulanmıştır.

\subsection{Veri Toplama ve Analiz}

Araştırma safhalarında verilerin elde edilmesinde "birincil kaynak araştırması" yöntemi kullanılmıştır. Veri toplama aşamasında anket tekniğinden yararlanılmıştır. Anket sorularının hazırlanmasında, Özkanal'a ait (2014) çalışması ve Sarı'ya ait (2012) çalışmasında kullanılan soru türlerinden yararlanılmıştır. Toplam on sekiz (18) sorudan oluşan anket metni güvenilirlik analizine tabi tutulmak üzere öncelikle 40 kişik bir öğrenci grubu üzerinde denenmiştir. Güvenilirlik analizi sonucunda "Cronbach's alpha katsayısı" "0.66" olarak hesaplanmıştır. Bu çalışma için toplanan veriler göz önünde bulundurulduğunda, "Cronbach Alpha güvenilirlik katsayısı' 0.973 olarak hesaplanmıştır. Dörnyei (2007:207)'ye göre 10 veya daha fazla soru içeren anketlerde 'Cronbach Alpha' katsayısının 0.80'den büyük olması anketin güvenilir bir veri toplama aracı olduğu anlamına gelir. Güvenilirlik analizinden sonra anket soruları bu kez yüz yüze görüşme tekniği ile üniversite öğrencilerine uygulanmıştır. Öğrencilerin verdikleri yanıtlar geniş bir veri seti oluşturmuştur. 
Anketin birinci bölümü cinsiyet, yaş, ikamet yeri, memleket gibi demografik sorulardan oluşmaktadır. İkinci bölümde ise öğrencilerin üniversitenin düzenlediği halkla ilişkiler faaliyetlerine memnuniyet düzeylerine yönelik sorular bulunmaktadır. Bu bölümde öğrencilere "hangi tür etkinliklerden hoşlanırsınız?", “ne sıklıkla etkinliklere katılırsınız?", "hangi tür etkinliklere katılırsınız?”, “etkinlikleri hangi tür araçlardan öğrenirisiniz?” v.b. sorular yöneltilmiştir. Öğrencilerin görüşleri beşli likert ölçeği ile anlamlandırılmaya çalışılmıştır.

Araştırmadan elde edilen veriler "SPSS 12,0" paket programı kullanılarak analiz edilmiştir. Yaş, cinsiyet, sınıf, memleket ve yerleşim durumu gibi demografik sorular ile kurumsal etkinliklerden duyulan memnuniyete ilişkin sorulara öğrenciler tarafından verilen yanıtların dağılımı betimsel istatistikler kullanılarak değerlendirilmiştir. Değerlendirmelerde yüzde/frekans tablolarından yararlanılmıştır.

\section{BULGULAR}

Çalışmanın bu bölümünde öncelikle katılımcılara uygulanan anketlerden elde edilen veriler sırası ile tablolar halinde gösterilmiştir. Daha sonraki aşamada tablolardaki veriler analiz edilerek bulgulara ulaşılmaya çalışılmıştır.

Tablo 3. Öğrencilerin Demografik Bilgilere Göre Dağılımı

\begin{tabular}{|c|c|c|}
\hline Cinsiyet & $\mathbf{n}$ & Oran \\
\hline Kadın & 285 & $\% 71,25$ \\
\hline Erkek & 115 & $\% 28,75$ \\
\hline Toplam & 400 & $\% 100$ \\
\hline \multicolumn{3}{|l|}{ Geldiğiniz Yer } \\
\hline Büyük şehir & 183 & $\% 45,8$ \\
\hline İl merkezi & 61 & $\% 15,3$ \\
\hline İlçe & 113 & $\% 28,3$ \\
\hline Köy & 43 & $\% 10,75$ \\
\hline Toplam & 400 & $\% 100$ \\
\hline \multicolumn{3}{|l|}{ Sinıf } \\
\hline 1. Sinif & 168 & $\% 42,0$ \\
\hline 2. Sinif & 130 & $\% 32,5$ \\
\hline 3. Sinif & 49 & $\% 12,3$ \\
\hline 4. Sinif & 53 & $\% 13,3$ \\
\hline Toplam & 400 & $\% 100,0$ \\
\hline \multicolumn{3}{|l|}{ Yerleşim Durumu } \\
\hline Evde yalnız yaşıyorum & 6 & $\% 1,5$ \\
\hline Evde arkadaşlarımla yaşıyorum & 93 & $\% 23,25$ \\
\hline Yurtta kaliyorum & 195 & $\% 48,75$ \\
\hline Apartta kaliyorum & 8 & $\% 2$ \\
\hline Apartta yalnız kalıyorum & 67 & $\% 16,75$ \\
\hline Apartta arkadaşlarımla kalıyorum & 29 & $\% 7,25$ \\
\hline Ailemle yaşıyorum & 2 & $\% 0,5$ \\
\hline Toplam & 400 & $\% 100$ \\
\hline
\end{tabular}


Tablo 3'e göre ankete katılanların \%71,25'ini kadınlar, \%28,75'ini erkekler oluşturmaktadır. Kadınların ankete daha fazla katılım gösterdikleri tespit edilmiştir. Ankete katılanların $\% 45,8$ 'i büyük şehirden, $\% 15,3$ 'ü il merkezinden $\% 28,3$ 'ü ilçeden ve \%10,8'inin köyden geldiği bilgisine ulaşılmıştır. Öğrencilerin eğitim düzeylerine göre dağılımı incelendiğinde, $\% 42$ 'sinin $1 . \sin 1 f, \% 32,5$ 'inin 2 . sınıf, \%12,3'ünün 3. sınıf ve \%13,3'ünün 4. sınıf olduğu görülmektedir. Buradan hareketle, ankete 1. sinıf öğrencilerinin daha fazla katılım sağladığını söyleyebiliriz. Araştırmaya katılanların yerleşim durumuna bakıldığında, öğrencilerin \%1,5'inin evde yalnız yaşadığ $1, \% 23$ 'ünün evde arkadaşları ile yaşadığ $1, \% 48,8$ 'inin yurtta kaldığı, öğrenci apartlarında yaşayanların \%16,8'inin öğrenci apartında yalnız kaldığı, \%7,3'ünün ise öğrenci apartında arkadaşları ile kaldığı ve \%0,5'inin ailesiyle yaşadığı görülmektedir.

Tablo 4. Etkinliklere Katılım Nedeni, Katılım Sıklığı ve Etkinliği Haber Alma Aracı

\begin{tabular}{lcc}
\hline Etkinliklere Katılım Nedeniniz & $\mathbf{n}$ & $\mathbf{\%}$ \\
\hline Kültürel Etkinlik Dersi Kapsamında Olduğu için & 43 & 10,75 \\
Kendim İstediğim İçin & 245 & 61,25 \\
Tavsiye Edildiği için & 112 & 28 \\
Toplam & 400 & 100 \\
\hline Etkinliklere Katılım Sıklığınız & $\mathbf{N}$ & $\mathbf{\%}$ \\
\hline Haftada Bir Kez & 40 & 10 \\
Haftada Birkaç Kez & 48 & 12 \\
Ayda Bir Kez & 71 & 17,75 \\
Ayda birkaç Kez & 59 & 14,75 \\
Çok Az Katılıyorum & 180 & 45 \\
Toplam & 398 & 99,5 \\
\hline Etkinlikleri Haber Aldığınız Enformasyon Aracı & $\mathbf{N}$ & $\mathbf{\%}$ \\
\hline Etkinlik Broşürü & 48 & 12,0 \\
Etkinlik Afişi & 144 & 36,0 \\
Davetiye & 21 & 5,3 \\
İnternet Araçları & 174 & 43,5 \\
Yayın Araçları & 13 & 3,3 \\
\hline Toplam & $\mathbf{4 0 0}$ & $\mathbf{1 0 0 , 0}$ \\
\hline
\end{tabular}

Tablo 4'te etkinliklere katılım nedeni, etkinliklere katılma sıklı̆g 1 ve öğrencilerin etkinlikleri öğrendikleri enformasyon aracı ile ilgili veriler yer almaktadır. Ankete katılanların \%10.75'i etkinliklere kültürel etkinlik dersi kapsamında, \%61.25'i kendi isteği ile \%28'i ise tavsiye üzerine katıldığını belirtmiştir. Buradan hareketle öğrencilerin yaklaşık \%10'luk bir kesimi dışındaki büyük çoğunluğu etkinliklere katılmaya isteklidir. Etkinliklerin öğrenciler için ilgi çekici olduğu düşünülmektedir. Öğrencilerin etkinliklere katılım sıklı̆̆ ile ilgili verilere göre, \%10'unun haftada bir kez, \%12'sinin haftada birkaç kez, \%17.75'inin ayda bir kez, \%14.75'inin ayda birkaç kez, \%45'inin çok az katıldığı görülmektedir. Bir önceki veriler çerçevesinde öğrencilerin etkinliklere katılmaya istekli oldukları düşünülürse, etkinliklere katılım sıklıklarının beklenilen seviyede olmadığı söylenebilir. Bu durum etkinliklerle ilgili tanıtma, duyurma ve bilgilendirme faaliyetlerinde aksaklıklar olabileceğini düşündürmektedir. Öğrencilerin etkinliklerden haberdar oldukları enformasyon araçları da çeşitlilik arz etmektedir. Öğrencilerin \%12'si broşürlerden, \%36's1 etkinlik afişlerinden, \%5,3'ü davetiyelerden, \%43,5'i internetten ve \%3,3'ü yayın araçlarından bilgi aldıklarını belirtmiştir. Buna göre öğrencilerin etkinliklerden haberdar olmasında internet önemli bir yer tutmaktadır. Ancak öğrencilerin yarısından fazlası etkinliklerle ilgili internet üzerinden bilgi sahibi olmadıklarını belirtmişlerdir. Bu çerçevede üniversitenin sosyal medya, web sitesi, blog gibi iletişim 
araçlarını daha etkin kullanması yararlı olabilir. Öte yandan, etkinlikleri afiş/broşür/davetiyelerden haber aldığını belirtmeyen öğrencilerin oranı yaklaşık \%47 gibi yüksek bir orandır. Bu verilerden hareketle üniversitenin afiş, poster, broşür, davetiye vb. yazılı ve görsel iletişim araçlarını daha etkin kullanması gerektiğini söylemek mümkündür.

Tablo 5. Öğrencilerin Cinsiyetlerine Göre Etkinliklere Katılım Sıklıkları

\begin{tabular}{|c|c|c|c|c|c|c|c|c|}
\hline & & & \multicolumn{5}{|c|}{ Cinsiyete Göre Katılım S1klığ1 } & \multirow[b]{3}{*}{$\mathrm{n} / \%$} \\
\hline & & & & Haftada & & & & \\
\hline & & & $\begin{array}{c}\text { Haftada Bir } \\
\text { Kez }\end{array}$ & $\begin{array}{c}\text { Birkaç } \\
\text { Kez }\end{array}$ & $\begin{array}{c}\text { Ayda Bir } \\
\text { Kez }\end{array}$ & $\begin{array}{c}\text { Ayda birkaç } \\
\text { Kez }\end{array}$ & $\begin{array}{c}\text { Çok Az } \\
\text { Katıliyorum }\end{array}$ & \\
\hline \multirow{8}{*}{ Cinsiyet } & \multirow{4}{*}{ Kadın } & $\mathrm{n}$ & 26 & 29 & 49 & 40 & 139 & 283 \\
\hline & & $\%$ Cinsiyet & $9.2 \%$ & $10.2 \%$ & $17.3 \%$ & $14.1 \%$ & $49.1 \%$ & 100.0 \\
\hline & & $\begin{array}{l}\text { \% Katılım } \\
\text { Sıkl1 }{ }_{1}\end{array}$ & $65.0 \%$ & $60.4 \%$ & $69.0 \%$ & $67.8 \%$ & $77.2 \%$ & 71.1 \\
\hline & & $\%$ Toplam & $6.5 \%$ & $7.3 \%$ & $12.3 \%$ & $10.1 \%$ & $34.9 \%$ & 71.1 \\
\hline & \multirow{4}{*}{ Erkek } & $\mathrm{n}$ & 14 & 19 & 22 & 19 & 41 & 115 \\
\hline & & \%Cinsiyet & $12.2 \%$ & $16.5 \%$ & $19.1 \%$ & $16.5 \%$ & $35.7 \%$ & 100.0 \\
\hline & & $\begin{array}{l}\text { \% Katılım } \\
\text { Sıkl1 } \breve{g}_{1}\end{array}$ & $35.0 \%$ & $39.6 \%$ & $31.0 \%$ & $32.2 \%$ & $22.8 \%$ & 28.9 \\
\hline & & $\%$ Toplam & $3.5 \%$ & $4.8 \%$ & $5.5 \%$ & $4.8 \%$ & $10.3 \%$ & 28.9 \\
\hline \multirow{4}{*}{ Toplam } & & $\mathrm{n}$ & 40 & 48 & 71 & 59 & 180 & 398 \\
\hline & & $\%$ Cinsiyet & $10.1 \%$ & $12.1 \%$ & $17.8 \%$ & $14.8 \%$ & $45.2 \%$ & 100.0 \\
\hline & & $\begin{array}{l}\text { \% Katılım } \\
\text { S1klı̆̆ } 1\end{array}$ & $100.0 \%$ & $100.0 \%$ & $100.0 \%$ & $100.0 \%$ & $100.0 \%$ & 100.0 \\
\hline & & $\%$ Toplam & $10.1 \%$ & $12.1 \%$ & $17.8 \%$ & $14.8 \%$ & $45.2 \%$ & 100.0 \\
\hline
\end{tabular}

Ankete katılan 283 kadın öğrenci \%9.2'si haftada bir kez etkinliklere katıldığını, \%7.3'ü haftada birkaç kez katıldığını, \%12.3'ü ayda bir kez katıldığını, \%10.1'i ayda bir kaç kez katıldığını, \%34.9'u etkinliklere çok az katıldığını belirtmiştir. Ankete katılan 115 erkek öğrencinin \%12.2'si haftada bir kez etkinliklere katıldığını, \%16.5'i haftada birkaç kez katıldığını, \%19.1'i ayda bir kez katıldığını, \%16.5'i ayda bir kaç kez katıldığını, \%35.7'si etkinliklere çok az katıldığını belirtmiştir. Buna göre öğrencilerin cinsiyetleri arasında etkinliklere gösterdikleri ilgi bakımından benzer bir dağlım olduğu ancak kadın öğrencilerin etkinliklere katılım sıklığının daha az olduğu söylenebilir.

Tablo 6. Öğrencilerin Katıldıkları Etkinlik Türleri

\begin{tabular}{|c|c|c|}
\hline $\begin{array}{l}\text { Bilimsel etkinliklere katılmaktan hoşlanır mısınız? } \\
\text { (Çalıştay/Eğitim/Konferans/Sempozyum/Kongre/Panel/Seminer/Söyleşi) }\end{array}$ & $\mathbf{N}$ & $\%$ \\
\hline Evet & 208 & 52,0 \\
\hline Hayır & 192 & 48,0 \\
\hline Toplam & 400 & 100 \\
\hline $\begin{array}{l}\text { Sosyal, külttürel ve sportif etkinliklere katılmaktan hoşlanır mısınız? } \\
\text { (Festival/Şenlik/Film/Gezi/Gösteri/Konser/ Spor/Tanıtım/Toplantı/Tören/Tiyatro) }\end{array}$ & $\mathbf{N}$ & $\%$ \\
\hline Evet & 365 & 91,2 \\
\hline Hayır & 35 & 8,8 \\
\hline Toplam & 400 & 100 \\
\hline $\begin{array}{l}\text { Bilimsel etkinliklere katılırsınız mısını? (Çalıştay/Eğitim/Konferans/Sempozyum/ } \\
\text { Kongre/Panel/Seminer/Söyleşi) }\end{array}$ & $\mathbf{N}$ & $\%$ \\
\hline Evet & 201 & 50,3 \\
\hline Hayır & 199 & 49,8 \\
\hline Toplam & 400 & 100 \\
\hline $\begin{array}{l}\text { Sosyal, kültürel ve sportif etkinliklere katılmaktan hoșlanır mısınız? } \\
\text { (Festival/Şenlik/Film/Gezi/Gösteri/Konser/ Spor/Tanıtım/Toplantı/Tören/Tiyatro) }\end{array}$ & $\mathbf{N}$ & $\%$ \\
\hline Evet & 363 & 90,8 \\
\hline Hayır & 35 & 8,8 \\
\hline Toplam & 398 & 100 \\
\hline
\end{tabular}


Ankete katılanların \%91,'i bilimsel etkinliklere katılmaktan hoşlandığını, \%50,3’ü ise bilimsel etkinliklere katıldığını belirtmiştir. Buna göre öğrencilerin bilimsel etkinliklere ilgi duyduğu söylenebilir. Ancak verilere dikkat edilirse öğrencilerin büyük bir kısmı bilimsel etkinliklerden hoşlandığını belirtmesine rağmen, sadece yarısı etkinliklere katılım göstermektedir. Bu veriler üzerinden bir değerlendirme yapılırsa öğrencilerin bilimsel etkinliklere daha fazla teşvik edilmesi gerektiği söylenebilir. Öte yandan, öğrencilerin \%91,2'si sosyal, kültürel ve sportif etkinliklere katılmaktan hoşlandığını, \%90,8'i sosyal ve kültürel etkinliklere katıldığını belirtmiştir. Aradaki farkın düşük olması öğrencilerin sosyal, kültürel ve sportif etkinlikleri daha çekici bulduklarını göstermektedir. Tablo 6'daki veriler çerçevesinde öğrencilerin sosyal, kültürel ve sportif etkinlikleri bilimsel etkinliklere nazaran daha ilgi çekici buldukları söylenebilir. Konuya kurumsal açıdan bakmak gerekirse üniversitenin sosyal, kültürel ve sportif etkinliklerin öğrencilere hitap etmesi bakımından başarılı olduğunu ancak bilimsel etkinlikler açısından öğrencilerin ilgisini artırmaya yönelik çalışmalar yapması gerektiğini söyleyebiliriz.

Tablo 7. Öğrencilerin Etkinlikler ile İlgili Görüşleri

\begin{tabular}{|c|c|c|c|c|c|c|c|c|c|c|c|c|}
\hline & \multicolumn{2}{|c|}{$\begin{array}{l}\text { Kesinlikle } \\
\text { Katılmıyor }\end{array}$} & \multicolumn{2}{|c|}{ Katılmıyor } & \multicolumn{2}{|c|}{ Kararsiz } & \multicolumn{2}{|c|}{ Katılıyor } & \multicolumn{2}{|c|}{$\begin{array}{l}\text { Kesinlikle } \\
\text { Katılıyor }\end{array}$} & \multicolumn{2}{|c|}{ Toplam } \\
\hline & $\mathbf{N}$ & $\%$ & $\mathbf{N}$ & $\%$ & $\mathbf{N}$ & $\%$ & $\mathbf{N}$ & $\%$ & $\mathbf{N}$ & $\%$ & $\mathbf{N}$ & $\%$ \\
\hline Toplumu tanımamda bana yardımcı oluyor. & 31 & 7.8 & 32 & 8.0 & 74 & 18.5 & 164 & 41.0 & 97 & 24.3 & 398 & 99.5 \\
\hline Kendimi tanımamda bana yardımcı oluyor. & 20 & 5.0 & 61 & 15.3 & 83 & 20.8 & 176 & 44.0 & 57 & 14.3 & 397 & 99.3 \\
\hline Etrafimda olanlar hakkında bilgimi arttırıyor. & 17 & 4.3 & 26 & 6.5 & 64 & 16.0 & 190 & 47.5 & 99 & 24.8 & 396 & 99.0 \\
\hline Merakımın giderilmesini sağlıyor. & 30 & 7.5 & 24 & 6.0 & 80 & 20.0 & 169 & 42.3 & 89 & 22.3 & 392 & 98.0 \\
\hline Yeni beceriler öğrenmemde bana yardımcı oluyor. & 29 & 7.3 & 44 & 11.0 & 89 & 22.3 & 171 & 42.8 & 65 & 16.3 & 398 & 99.5 \\
\hline Yalnızlığımı gideriyor. & 59 & 14.8 & 61 & 15,3 & 95 & 23,8 & 112 & 28,0 & 70 & 17,5 & 397 & 99,3 \\
\hline Can sıkıntımı gideriyor. & 38 & 9,5 & 33 & 8,3 & 94 & 23,5 & 140 & 35,0 & 93 & 23,3 & 398 & 99,5 \\
\hline Mutlu olmamı sağlıyor. & 35 & 8,8 & 36 & 9,0 & 75 & 18,8 & 168 & 42,0 & 84 & 21,0 & 398 & 99,5 \\
\hline İyi zaman geçirmemi sağliyor. & 29 & 7,3 & 19 & 4,8 & 64 & 16,0 & 172 & 43,0 & 111 & 27,8 & 395 & 98,8 \\
\hline Sosyal bir çevre oluşturmama katkı sağlıyor. & 28 & 7,0 & 39 & 9,8 & 89 & 22,3 & 152 & 38,0 & 90 & 22,5 & 398 & 99,5 \\
\hline Başka kişilerle iletişim kurabiliyorum. & 32 & 8,0 & 37 & 9,3 & 94 & 23,5 & 156 & 39,0 & 80 & 20,0 & 399 & 99,8 \\
\hline Arkadaş ediniyorum. & 30 & 7,5 & 51 & 12,8 & 110 & 27,5 & 133 & 33,3 & 75 & 18,8 & 399 & 99,8 \\
\hline Kendimi rahat hissediyorum. & 27 & 6,8 & 26 & 6,5 & 114 & 28,5 & 156 & 39,0 & 76 & 19,0 & 399 & 99,8 \\
\hline Eğleniyorum. & 18 & 4,5 & 19 & 4,8 & 72 & 18 & 180 & 45,0 & 110 & 27,5 & 399 & 99,8 \\
\hline Heyecan veriyor. & 28 & 7,0 & 18 & 4,5 & 110 & 27,5 & 161 & 40,3 & 82 & 20,5 & 399 & 99,8 \\
\hline Eğlence yerlerine gitme ihtiyacımı karşılıyor. & 33 & 8,3 & 32 & 8,0 & 94 & 23,5 & 156 & 39,0 & 82 & 20,5 & 397 & 99,3 \\
\hline Kişisel gelişimime katk1 s & 37 & 9,3 & 20 & 5,0 & 90 & 22,5 & 169 & 42,3 & 81 & 20,3 & 397 & 99,3 \\
\hline Arkadaşlarımla etkinlikle ilgili konuşabiliyorum. & 28 & 7,0 & 21 & 5,3 & 85 & 21,3 & 181 & 45,3 & 82 & 20,5 & 397 & 99,3 \\
\hline Günlük hayatım içerisinde rahatlamamı sağlıyor. & 27 & 6,8 & 35 & 8,8 & 88 & 22.0 & 186 & 46,5 & 60 & 15,0 & 396 & 99,0 \\
\hline Sıkıntılarımdan uzaklaşmamı sağlıyor. & 29 & 7,3 & 36 & 9,0 & 109 & 27,3 & 160 & 40,0 & 64 & 16,0 & 398 & 99,5 \\
\hline Boş vaktimi değerlendirmemi sağlıyor. & 24 & 6,0 & 20 & 5,0 & 65 & 16,3 & 194 & 48,5 & 93 & 23,3 & 396 & 99,0 \\
\hline Günlük yaşamdaki stresten uzaklaşmamı sağlıyor. & 31 & 7,8 & 25 & 6,3 & 85 & 21,3 & 178 & 44,5 & 80 & 20,0 & 399 & 99,3 \\
\hline Kültürel gelişimime katkı sağlıyor. & 23 & 5,8 & 32 & 8,0 & 81 & 20,3 & 166 & 41,5 & 95 & 23,8 & 397 & 99,3 \\
\hline İlgilendiğim konulara yer veriliyor. & 37 & 9,3 & 34 & 8,5 & 89 & 22,5 & 167 & 41,8 & 73 & 18,3 & 400 & 100 \\
\hline Sosyal gelişimime katkı sağlıyor. & 30 & 7,5 & 21 & 5,3 & 85 & 21,3 & 193 & 48,3 & 70 & 17,5 & 399 & 99,8 \\
\hline Öz güven sağlıyor. & 32 & 8,0 & 37 & 9,3 & 95 & 23,8 & 174 & 43,5 & 61 & 15,3 & 399 & 99,8 \\
\hline Başarı hissi v & 42 & 10,5 & 49 & 12,3 & 124 & 31,0 & 133 & 33,3 & 51 & 12,8 & 399 & 99,8 \\
\hline Etkinl & 37 & 9,3 & 73 & 18,3 & 151 & 37,8 & 92 & 23,0 & 43 & 10,8 & 396 & 99,0 \\
\hline Sanat, kültür ve sosyal alanlarda bilmediklerimi öğreniyorum. & 24 & 6,0 & 42 & 10,5 & 100 & 25,0 & 161 & 40,3 & 71 & 17,8 & 398 & 99,5 \\
\hline Etkinlikleri talep etmek alışkanlıktır. & 49 & 12,3 & 67 & 16,8 & 115 & 28,8 & 115 & 28,8 & 50 & 12,5 & 396 & 99,0 \\
\hline Etkinliklere katılmak beni dinlendiriyor. & 31 & 7,8 & 43 & 10,8 & 131 & 32,8 & 144 & 36,0 & 50 & 12,5 & 399 & 99,8 \\
\hline Etkinliklere katılmak bana heyecan veriyor. & 25 & 6,3 & 41 & 10,3 & 91 & 22,8 & 184 & 46,0 & 55 & 13,8 & 396 & 99,0 \\
\hline İlgilend & 14 & 3,5 & 35 & 8,8 & 73 & 18,3 & 193 & 48,3 & 83 & 20,8 & 398 & 99,5 \\
\hline Katıldiğ & 23 & 5,8 & 29 & 7,3 & 65 & 16,3 & 210 & 52,5 & 70 & 17,5 & 397 & 99,3 \\
\hline Hayata bakış açımı şekillendirmeme yardımcı oluyor. & 34 & 8,5 & 43 & 10,8 & 89 & 22,3 & 172 & 43,0 & 60 & 15,0 & 398 & 99,5 \\
\hline Toplumsal yaşama katılımımı sağlıyor. & 27 & 6,8 & 40 & 10,0 & 112 & 28,0 & 147 & 36,8 & 72 & 18,0 & 398 & 99,5 \\
\hline Sikıntılarımı unutturuyor. & 36 & 9,0 & 50 & 12,5 & 120 & 30,0 & 130 & 32,5 & 61 & 15,3 & 397 & 99,3 \\
\hline Sıkıcı işlerden kurtuluyorum. & 32 & 8,0 & 65 & 16,3 & 100 & 25,0 & 129 & 32,3 & 71 & 17,8 & 397 & 99,3 \\
\hline Dertlerimi unutturuyor. & 51 & 12,8 & 59 & 14,8 & 111 & 27,8 & 122 & 30,5 & 56 & 14,0 & 399 & 99,8 \\
\hline Stresten kurutuluyorum. & 35 & 8,8 & 40 & 10,0 & 103 & 25,8 & 148 & 37,0 & 72 & 18,0 & 398 & 99,5 \\
\hline Rahatlamama yardımcı oluyor. & 36 & 9,0 & 37 & 9,3 & 107 & 26,8 & 159 & 398 & 61 & 15,3 & 400 & 100 \\
\hline Kendimi duygusal olarak iyi hissetı & 24 & 6,0 & 35 & 8,8 & 92 & 23,0 & 170 & 42,5 & 79 & 19,8 & 400 & 100 \\
\hline Zamanın hızlı geçmesine yardımcı oluyor. & 25 & 6,3 & 33 & 8,3 & 89 & 22,3 & 152 & 38,0 & 96 & 24,0 & 395 & 98,8 \\
\hline Başka insanlarla gruplar içinde olabildiğim etkinlikleı & 38 & 9,5 & 39 & 9,8 & 89 & 22,3 & 152 & 38,0 & 77 & 19,3 & 395 & 98,0 \\
\hline Etkinliklere birlikte katıldığım insanlara karşı güçlü başlılık hissediyorum & 34 & 8,5 & 31 & 7,8 & 132 & 33,0 & 134 & 33,5 & 66 & 16,5 & 397 & 99,3 \\
\hline Katıldığım etkinlikleri özgürce seçerim. & 23 & 5,8 & 32 & 8,0 & 59 & 14,8 & 159 & 39.8 & 125 & 31,3 & 398 & 99,5 \\
\hline Etkinlikler entelektüel açıdan çekicidir. & 24 & 6,0 & 38 & 9,5 & 113 & 28,3 & 152 & 38,0 & 67 & 16,8 & 394 & 98,5 \\
\hline Etkinliklere katıldığım alanlar/yerler iyi dizayn edilmiştir. & 24 & 6,0 & 67 & 16,8 & 133 & 33 , & 123 & 30,8 & 52 & 13,0 & 399 & 99,8 \\
\hline Etkinliklere katıldığım yerler benim hoşuma giden yerlerdir. & 22 & 5,5 & 45 & 11,3 & 127 & 31,8 & 133 & 33,3 & 71 & 17,8 & 398 & 99,5 \\
\hline Etkinliklere katıldığım mekânlar ilgi çekicidir. & 35 & 8,8 & 53 & 13,3 & 126 & 31,5 & 116 & 29,0 & 68 & 17,0 & 398 & 99,5 \\
\hline
\end{tabular}


Öğrencilere bilimsel, sosyal, kültürel ve sportif etkinliklere katılım nedenleri ile etkinliklerle ilgili algılarına yönelik çok sayıda soru sorulmuştur. Sonuçlar Tablo 6'da gösterilmektedir. Sonuçlar "katılıyorum ve "kesinlikle katılıyorum" seçeneklerinin toplamına göre değerlendirilirse; öğrencilerin etkinliklere katılma nedenleri ve etkinliklerle ilgili algıları daha iyi anlaşılabilmektedir. Öğrencilerin \%72,5'i etkinliklere katılma nedeni sorusuna "beni eğlendiriyor" şeklinde yanıt vermiştir. Etkinlikler beni eğlendiriyor cevabı veren öğrenciler 1. sırada yer almaktadır. Bu oranı \%72,3 ile "bilgimi artırıyorum"; \% 71, 8 ile boş vaktimi değerlendiriyorum"; \%70, 8 ile "iyi zaman geçiriyorum"; \%70 ile "katıldığım etkinlikle ilgili bilgi olmamı sağlıyorum” seçenekleri izlemektedir. En düşük seçeneklere bakılacak olursa öğrencilerin \%33, 8'i "etkinliklerin kendisi için ilginç olduğunu", \%41, 3'ü "etkinliklerin kendisi için alışkanlık olduğunu", \%44,5'i “etkinliklerin sıkıntılarını unutturduğunu”, \%45,5'i “etkinliklerin yalnızlığını giderdiğini, \%46,1'i ise etkinliklerin başarı hissi verdiğini" belirtmişlerdir. Veriler üzerinden bir değerlendirme yapmak gerekirse öğrencilerin kurumsal etkinlikleri büyük oranda yeterli buldukları söylenebilir.

Dikkat çekici diğer veriler ise şöyledir. Etkinlikleri özgürce seçtiğini beyan eden öğrencilerin oranı $\% 71,1$ 'dir. $\mathrm{Bu}$ üniversitenin öğrenciler üzerinde etkinliklere katılmaları hususunda bir yönlendirme yapmadığı şeklinde yorumlanabilir. Öğrencilerin \%60,1 gibi büyük bir kısmı etkinliklerin ilgi duydukları konulara yer verdiğini belirtmiştir. Bu yüksek bir oran olsa da yaklaşık \%40'lık bir öğrenci kesiminin bu soruya olumsuz yanıt vermesi kurumsal açıdan düşündürücüdür. Bir başka önemli husus "etkinliklerin entelektüel çekiciliği olduğunu" düşünen öğrencilerin sayısıdır. Katılımcıların \%54,8’i etkinlikleri entelektüel açıdan yeterli bulmaktadır. Oran yarıdan fazla olmakla birlikte düşük kabul edilebilir. Üniversitenin etkinliklerin entelektüel çekiciliğini artırmaya yönelik çalışmalar yapması yerinde olabilir. Öğrencilerin etkinliklerin yapıldığı fiziki mekânlar ile ilgili görüşleri de bulunmaktadır. Araştırma sonuçlarına göre öğrencilerin \%46's1 “etkinliklere katıldığı mekânları ilgi çekici” bulurken, \%54'ü bu soruya olumsuz yanıt vermiştir. Ayrıca öğrencilerin sadece \%43,8'i "fiziki mekânların iyi dizayn edildiğini” düşünmektedir. Bu iki soruya verilen yanıtlar kendi arasında tutarlılığını korumaktadır. $\mathrm{Bu}$ bağlamda, üniversitenin fiziki mekânların iyileştirilmesi adına bu sonucu da dikkate alması faydalı olabilir.

\section{SONUÇ VE TARTIŞMA}

Halkla ilişkilerin kurumsal hedeflere ulaşmada ve paydaşlar ile iletişimi güçlendirmede önemli bir yeri olduğu bilinmektedir. Ancak halkla ilişkilere yönelik faaliyetlerin amaçlarına ulaşmasının başlıca yolu hedef kitlenin memnuniyetinin kazanılmasından geçmektedir. Bu araştırma, Artvin Çoruh Üniversitesi lisans öğrencilerinin üniversite bünyesinde gerçekleştirilen sosyal, kültürel, sportif ve bilimsel etkinliklere yönelik memnuniyet düzeylerinin belirlenmesi amacıyla yapılmıştır. Araştırma sonuçları kurumsal etkinliklerle ilgili karar alma ve uygulama süreçlerinde birtakım aksaklıkların olduğunu göstermektedir.

Öncelikle araştırma verilerine göre öğrencilerin kurumsal etkinlikleri genellikle ilgi çekici buldukları söylenebilir. Buna rağmen, öğrencilerin etkinliklere katılım oranı beklenen düzeyin altındadır. Bu durum etkinliklerin hedef kitleye duyurulmasında birtakım aksaklıklar olabileceği yönünde değerlendirilmektedir. Örneğin öğrencilerin büyük bir bölümü etkinlikleri internet kaynakları üzerinde öğrenmediklerini belirtmişlerdir. Hâlbuki günümüzde internet iletişim sürecinin en temel mecralarından birisidir. $\mathrm{Bu}$ çerçevede üniversitenin sosyal medya hesapları, web siteleri ve bloglar gibi iletişim araçlarını daha etkin kullanmasının bilgi iletiminde etkili olabileceği değerlendirilmektedir.

Araştırmanın bir diğer önemli sonucu öğrencilerin bilimsel, sosyal, kültürel ve sportif etkinlikler ile ilgili görüşleridir. Sonuçlar, öğrencilerin büyük bir kısmının bilimsel etkinliklere katılmaktan hoşlandıklarını göstermektedir. Buna rağmen öğrencilerin bilimsel etkinliklere katılım oranları beklenilenden düşüktür. Öte yandan, öğrencilerin büyük kısmı sosyal, kültürel ve sportif etkinlikleri bilimsel etkinliklere tercih ettiklerini belirtmişlerdir. Bu sonuçlar çerçevesinde, öğrencilerin bilimsel etkinliklere katılımını teşvik etmeye yönelik girişimlerde bulunulması gerektiğini söylemek mümkündür. Örneğin, bilimsel etkinliklerle ilgili karar alma, planlama ve düzenleme aşamalarında, öğrencilerin aktif bir şekilde rol alması sağlanabilir. 
Ayrıca öğrencilerin yarısından fazlasının fiziki mekânları yeterli bulmadığı görülmektedir. Bu çerçevede, üniversitenin fiziki mekânların iyileştirilmesi yönünde gayret sarf etmesi olumlu olabilir.

Araştırma kapsamında dikkate değer bir diğer değerlendirme öğrencilerin etkinliklere özgürce katılıp katılmadıkları noktasında yapılabilir. Zira araştırma sonuçları öğrencilerin yaklaşık üçte birlik kısmının etkinliklere özgür iradesi dışında katıldığını göstermektedir. Bu durum öğrencilerin etkinliklerle amaçlanan kazanımları elde etmelerini engelleyici bir unsur olabilir. Ayrıca, öğrencilerin istemedikleri halde kurumsal etkinliklere katılmak zorunda bırakılması halkla ilişkiler faaliyetlerinin misyonu ve hedefleri ile de bağdaşmamaktadır.

Sonuç olarak bu araştırma sonuçlarının üniversitenin yetkili birimlerince incelenmesi ve dikkate alınması gerektiğini söyleyebiliriz. Böylelikle aksaklıkların giderilmesi için etkili tedbirlere başvurulabilir. İyileştirme sürecinin başlaması, hem üniversitenin kurumsal gelişimi açısından hem de araştırmanın amacına ulaşması açısından önemlidir. Bu suretle, kurumsal etkinliklerde yönetişimi esas alan, katılımcı ve yenilikçi bir anlayış geliştirilmesinin önü açılabilir. Önümüzdeki dönemde, üniversitece düzenlenen etkinliklerin verimliliğinde artış olup olmadığı yeni araştırmalar ile tespit edilebilir.

\section{Çatışma Beyanı}

Çalışma hazırlanırken; veri toplanması, sonuçların yorumlanması ve makalenin yazılması aşamalarında herhangi bir çıkar çatışması alanı bulunmamaktadır.

\section{KAYNAKLAR}

Alikılıç, Ö. \& Onat, F. (2007). Bir Halkla İlişkiler Aracı Olarak Kurumsal Bloglar. Journal of Yasar University, 2(8), 899-927.

Altan, Y. (2016). Türk Kamu Personel Rejiminde Reform İhtiyacı: Reformu Gerektiren Dış Etkenler Ekseninde Bir Değerlendirme. Mehmet Akif Ersoy Üniversitesi Sosyal Bilimler Enstitüsü Dergisi, 8(15), 381-398.

Beşballı: G. \& Öztürk, Z. (2017). Artvin Çoruh Üniversitesi Öğrencilerinin Harcamalarının Artvin Ekonıisine Katkısı. Karadeniz Araştımalarl, 14(56), 135-157.

Bozlağan, R. (2008). Geleneksel Kamu Yönetimi Yaklaşımı, Yeni Kamu Yönetimi Yaklaşımı ve Yerel Yönetimlere Etkileri. R. Bozlağan ve Y. Demirkaya (Ed.), Türkiye'de Yerel Yönetimler içinde (1. Baskı., ss. 1-28). Ankara: Nobel Yayın Dağıtım.

Byerly, C. M. (1993). Toward a Comprehensive History of Public Relations. Annual Meeting of the Association for Education in Journalism and Mass Communication içinde (ss. 1-23). Kansas City.

Demirkaya, Y. (2006). Küreselleşmenin Kamu Yönetimi Üzerine Etkisi: Türkiye Örneği. Avrupa Araştırmaları Dergisi, 14(2), 133-150.

Dornyei, Z. (2007). Research Methods in Applied Linguistics: Quantitative. Qualitative and.

Froehlich, R. ve Rüdiger, B. (2006). Framing political public relations: Measuring success of political communication strategies in Germany. Public Relations Review, 32(1), 18-25. doi:10.1016/j.pubrev.2005.10.003

Grunig, J. E. \& Hunt, T. (1984). Managing Public Relations. Fort Worth, TX: Holt, Rinehart \& Winston.

Harlow, R. (1976). Building a Public Relations Definition. Public Relations Review, 2(4), 34-42.

Hon, L. C. \& Grunig, J. E. (1999). Guidelines for Measuring Relationships in Public Relations. Institute for Public Relations.

İnalcık, H. (2019). Rönesans Avrupası (12. Baskı.). İstanbul: Türkiye İş Bankası Yayınları.

Krejcie, R. V. \& Morgan, D. W. (1970). Determining sample size for research activities. Educational and psychological measurement, 30(3), 607-610

Kent, M. L. \& Taylor, M. (2002). Toward a dialogic theory of public relations. Public Relations Review, 28(1), $21-$ 37. doi:10.1016/S0363-8111(02)00108-X

Kim, Y. (2001). Measuring the Economic Value of Public Relations. Journal of Public Relations Research, 13(1), 326. doi:10.1207/S1532754XJPRR1301_2 
Lindenwann, W. K. (1997). Setting minimum standards for measuring public relations effectiveness. Public Relations Review, 23(4), 391-402. doi:10.1016/S0363-8111(97)90053-9

Metin, H. \& Altunok, M. (2002). Karşılaştırmalı Bir Yaklaşımla Kamu Yönetimi ve Özel Sektörde Halkla İlişkiler. Kocaeli Üniversitesi Sosyal Bilimler Enstitüsü Dergisi, 3(1), 79-99.

Onat, F. \& Aşman-Alikılıç, Ö. (2008). Sosyal Ăg Sitelerinin Reklam ve Halkla İlişkiler Ortamı Olarak Değerlendirilmesi. Journal of Yasar University, 3(9), 1111-1143.

Öndoğan, A. G. (2010). Üniversite Kütüphanelerinde Yürütülen Halkla İlişkiler Faaliyetlerinin Müşteri Memnuniyeti Üzerine Etkisi. Türk Kütüphaneciliği, 24(3), 439-470.

Öner, Ş. (2001). Belediyelerde Yönetime Katılmada Halkla İlişkilerin Rolü ve Önemi. Dokuz Eylül Üniversitesi Sosyal Bilimler Enstitüsü Dergisi, 3(2), 100-114.

Özkanal, B. (2014). Bir Halkla İlişkiler Aracı Olarak Kurumsal Etkinlikler: Anadolu Üniversitesi Örneği. Erciyes Iletişim Dergisi, 3(3), 12-26.

Roberts-Bowman: (2016). What is Public Relations? A. Theaker (Ed.), The Public Relations Handook içinde (5. Bask1., ss. 1-26). New York: Routledge.

Saran, M., Coşkun, G., İnal-Zorel, F. \& Aksoy, Z. (2011). Üniversitelerde Sosyal Sorumluluk Bilincinin Geliştirilmesi: Ege Üniversitesi Topluma Hizmet Uygulamaları Dersi Üzerine Bir Araştırma. Journal of Yasar University, 22(6), 3732-3747.

Sar1, M. (2012). An Investigation of High School Students' Participation in Extracurricular Activities. Kuramsal Eğitimbilim Dergisi, 5(1), 72-89.

Theaker, A. (Ed.). (2016). The Public Relations Handbook (5. Bask1.). Abington: Routledge.

Ural, E. G. (2002). İtibar yönetimi: Değer Yaratan Bir Halkla İlişkiler Çalışması Olarak itibar Yönetimi. İstanbul Ticaret Üniversitesi Dergisi, 83-93.

Uygun: V. (2018). Türk Kamu Yönetiminde Halkla İlişkiler Kavramının Konumu: Anlayış, Uygulama ve Karşılaştırma. Uluslararası Sosyal ve Beşeri Bilimler Dergisi, 1(3), 20-36.

Uzunoğlu, E. \& Öksüz, B. (2008). Kurumsal İtibar Riski Yönetimi: Halkla İlişkilerin Rolü. Selçuk İletişim Dergisi, 5(3), 111-123.

Waters, R. D. (2009). Measuring stewardship in public relations: A test exploring impact on the fundraising relationship. Public Relations Review, 35(2), 113-119. doi:10.1016/j.pubrev.2009.01.012

Yağmurlu, A. (2011). Kamu Yönetiminde Halkla İlişkiler ve Sosyal Medya. Selçuk İletişim Dergisi, 7(1), 5-15. 